\title{
Agile supply chain strategy and supply chain performance: Complementary roles of supply chain practices and information systems capability for agility
}

\begin{abstract}
The paper examines the mediating effect of supply chain (SC) practices on the relationship between agile supply chain (ASC) strategy and supply chain (SC) performance. It further examines the moderating effect of information systems (IS) capability for agility on this mediated relationship. Using the theoretical lenses of complementarity and the information processing view of the supply chain, we hypothesize that strategic supplier partnership, customer relationship, postponement, and lean practices, mediate the relationship between ASC strategy and SC performance. We further hypothesize that IS capability for agility moderates each of these mediated relationships. We empirically test the hypotheses using survey data from members of senior and executive management in the logistics/supply chain functions, of 205 firms. The paper contributes to the literature on agile supply chains by theoretically explaining and empirically demonstrating how SC practices and IS capability for agility act together to effect a positive relationship between agile supply chain strategy and supply chain performance.
\end{abstract}

Keywords: supply chain agility, supply chain practices, supply chain performance, information systems capability for agility, supply chain information systems, moderated mediation analysis, structural equation modeling. 


\section{Introduction}

Supply chain agility is essential for a focal firm to produce according to varying customer needs. In order that the firm can manufacture in response to what customers require, its supply chain should be agile, that is, respond quickly to volatile demand and short product life cycles (Blome, Schoenherr, and Rexhausen 2013; Gligor, Esmark, and Holcomb 2015). Supply chain agility is critical, for rapidly introducing new products in response to changing customer needs (Qi, Zhao, and Sheu 2011) and reacting effectively to changes in delivery requirements of quantity and time (Yusuf et al. 2004). As an example of the first, Zara's highly responsive supply chain allows the company to produce and offer new designs from week to week and make them available to its stores worldwide in just 15 days (Lee 2004; Ferdows, Lewis, and Machuca 2004). As an example of the second, Seven-Eleven replenishes its stores with a wide variety of products with the appropriate quantities within twelve hours of customers placing orders (Ferdows, Lewis, and Machuca 2004). Both are due in a large part to the agility of the respective supply chains.

Agility in supply chains is embodied in the 'agile supply chain strategy' (Fisher 1997; Christopher 2000). An agile supply chain (ASC) strategy is one that that has the objective of quick and effective response of the supply chain to changing customer needs. The literature focuses on the relationship between ASC strategy and performance of the focal firm, on antecedents of agility, and on product characteristics of agile supply chains (Blome, Schoenherr, and Rexhausen 2013; Lee 2002; Goldsby, Griffis, and Roath 2006). However it does not explain how an ASC strategy can improve supply chain (SC) performance. From the perspective of supply chain practitioners too, a recent study (Cecere 2012) showed that while 89\% of the companies surveyed recognized the importance of the ASC strategy, few understood how it could lead to improved SC performance. The objective of this paper is thus to explain how an ASC strategy can improve SC performance.

We address this objective through the lens of two theoretical concepts. The first is the idea of complementarity between supply chain strategy and supply chain (SC) practices. We suggest that particular SC practices complement an ASC strategy by providing a positive mediating link between ASC strategy and SC performance. The second is the informationprocessing view of the firm (Galbraith 1973). Applying this view, we examine if an Information Systems (IS) capability for agility strengthens this mediating effect of the SC practices. We thus address the paper's objective by answering the following research questions: (1) Do SC practices mediate the relationship between ASC strategy and SC performance?; and (2) Does IS capability for agility positively moderate this mediating relationship?

Theorizing from the supply chain and IS literatures, we develop hypotheses explaining (1) the mediating effect of three SC practices (namely, Strategic Supplier Partnership, Customer Relationship and Postponement) on the relationship between ASC strategy and SC performance, and (2) the positive moderating effect of IS capability for agility on these mediating relationships. We test our hypothesis through structural equation modeling, and moderatedmediation analysis applied to survey data from senior executives in supply chain management, materials management, and procurement roles from 205 manufacturing firms.

The paper's contribution is in conceptualizing the complementing effects of particular SC practices and IS capability for agility, under which ASC strategy is positively associated with SC performance. It makes two contributions. First, it explains how ASC strategy improves SC performance by showing that SC practices provide positive linking effects between ASC strategy and SC performance. The relationship between supply chain practices and ASC strategy has not 
been examined before. Second, we explain when these linking effects are further boosted - that is, in the presence of IS capability for agility. For supply chain and operations management practitioners the paper shows that implementing the three practices of Strategic Supplier Partnership, Postponement and Customer Relationship are effective ways to improve SC performance from an ASC strategy. Further, it offers supply chain managers overseeing an agile supply chain, guidance for what kind of IS applications they should adopt.

\section{Theoretical development}

\subsection{Complementarity between agile supply chain strategy and supply chain practices}

'Supply chain strategy' specifies the goals of the supply chain; it determines the overall focus of the supply chain with respect to cost and responsiveness. The nature of key supply chain processes such as procurement, inventory management, logistics and customer service is influenced by the supply chain strategy (Qi, Zhao, and Sheu 2011). 'ASC strategy' is defined as a supply chain strategy that has the objective of quick and effective response of the supply chain to changing customer needs (Huang, Uppal, and Shi 2002; Lin, Chiu, and Chu 2006). Agility in supply chains is embodied in the 'agile supply chain strategy' (Fisher 1997; Christopher 2000). Studies focus on the relationship between ASC strategy and the operational and financial performance of the focal firm (Blome, Schoenherr, and Rexhausen 2013; Swafford, Ghosh, and Murthy 2006), and on antecedents of agility such as flexibility of procurement, manufacturing, and distribution (Swafford, Ghosh, and Murthy 2006; Purvis, Gosling, and Naim 2014), knowledge sharing, and virtual integration (Lee 2002; Goldsby, Griffis, and Roath 2006). Studies have also looked at conditions under which an ASC strategy is appropriate such as the presence of specific product characteristics (Fisher 1997; Lee 2002; Huang, Uppal, and Shi 2002). However, the literature does not address the question of how or why an ASC strategy can improve supply chain SC performance.

'SC practices' are sets of activities and processes that accomplish particular tasks in the supply chain ( $\mathrm{Li}$ et al. 2005). Drawing from the notion that strategy is executed through a distinctive set of processes or activities (Porter 1996), we suggest that an ASC strategy when executed through particular SC practices can achieve improved SC performance. This notion is also supported by the concept of complementarity (Milgrom and Roberts 1995) according to which a match between a firm's strategy, processes and structure is necessary for desired organizational outcomes such as performance and profit. Particular SC practices should therefore exist concurrently and in complement with the specific supply chain strategy, to appropriate performance benefits from that orientation. Specifically, in this paper we identify three SC practices that are complementary to an ASC strategy, and are expected to provide a positive link or bridge between an ASC strategy and SC performance.

\subsection{Information processing requirements of the agile supply chain}

According to the information-processing view of the firm (Galbraith 1973), information is required to execute the firm's processes, representing the firm's information processing requirements. To satisfy these requirements the firm needs to deploy matching information processing mechanisms. Applying this perspective to the context of supply chains, information required to execute processes or activities in the supply chain represents the supply chain's information processing needs. Information systems in the supply chain should then provide the focal firm with the ability to process information in support of these processes and activities; 
they represent the supply chain's information processing abilities. A match between information processing needs and abilities is required for realizing benefits from deploying information systems in the supply chain. Literature examines the role of technology applications in support of supply chain integration (McLaren, Head, and Yuan 2004; Rai, Patnayakuni, and Seth 2006), supplier relationships (Subramani 2004; Sanders 2008) and procurement (Premkumar, Ramamurthy, and Saunders 2005). However it does not explain what the specific information processing requirements of an ASC are, and how information systems can support them.

We theorize that the ASC strategy points to two information requirements. First, timely access to information on market trends, customer preferences and competitive action is needed to be able to respond to changing demand by introducing new products (Whitten, Green Jr., and Zelbst 2012; Lee 2002). Second, information that facilities collaboration and co-ordination with partners such as timely exchange of schedules, lead times and inventory is needed for quickly designing and delivering those products (Swafford, Ghosh, and Murthy 2006) and effectively executing inter-firm processes (Saraf, Langdon, and Gosain 2007). These information requirements can be addressed by a portfolio of IS applications that should have capabilities for market intelligence and understanding, and inter-organizational information-sharing, communication and co-ordination (Sabherwal and Chan 2001). We describe them as 'IS capability for agility'. We define IS capability for agility as the extent to which the firm has IS applications that enable sharing of information with customers and suppliers, support market search and monitoring, facilitate future scenario planning, and aid in the introduction of new products and services. We suggest that IS capability for agility further boosts the benefits from the three SC practices by creating a fit between information processing needs and abilities. That is, the presence of 'IS capability for agility' strengthens the mediating effect of the SC practices between ASC strategy and SC performance.

We present Figure 1 as a review of our theorizing logic, and as the basis for the paper's hypotheses developed in the next section. We suggest each SC practice to be a mediating mechanism through which an ASC strategy links to SC performance. To that end we propose that each of the three SC practices will have a positive mediating effect between ASC strategy and SC performance. Next, we suggest that the concurrent presence of IS capability for agility positively moderates the mediated effect of the SC practices on the relationship between ASC strategy and SC performance.

\section{-Insert Figure 1 Approximately Here}

\section{Research hypotheses}

Figure 2 depicts our hypothesized relationships between ASC strategy, three SC practices Strategic Supplier Partnership, Customer Relationship and Postponement, SC performance, and IS capability for agility. Table 1 defines these constructs. We hypothesize that each of three SC practices mediates the relationship between ASC strategy and SC performance. We then hypothesize that IS capability for agility positively moderates the mediating effect of each SC practice on the relationship between ASC strategy and SC performance. We next describe the logic for the research hypotheses. 


\begin{tabular}{|c|c|c|}
\hline \begin{tabular}{|l} 
Construct \\
\end{tabular} & Definition & Literature \\
\hline $\begin{array}{lll}\text { Agile } & \text { Supply } & \text { Chain } \\
\text { (ASC) } & \text { Strategy } & \end{array}$ & $\begin{array}{l}\text { Supply chain strategy that is directed } \\
\text { toward quick and effective response to } \\
\text { changing customer needs. }\end{array}$ & $\begin{array}{l}\text { Huang et al. (2002); Lin et al. (2006); } \\
\text { Stevenson and Spring (2007); Qi et } \\
\text { al. (2011); Witten et al. (2012); and } \\
\text { Lee (2002). }\end{array}$ \\
\hline \begin{tabular}{|lll} 
Supply & Chain & (SC) \\
Practices & & \\
\end{tabular} & $\begin{array}{l}\text { Sets of activities and processes that } \\
\text { accomplish particular tasks in the } \\
\text { supply chain. }\end{array}$ & Li et al. (2005). \\
\hline \begin{tabular}{|ll} 
Strategic & Supplier \\
Partnership & \\
\end{tabular} & $\begin{array}{l}\text { Processes/activities for developing a } \\
\text { close and long-term relationship } \\
\text { between the organization and its } \\
\text { suppliers. }\end{array}$ & $\begin{array}{l}\text { Li et al. (2005); Monczka et al. } \\
\text { (1998); Maloni and Benton, (1997); } \\
\text { Gunasekaran et al., (2001); and Lao } \\
\text { et al. (2010). }\end{array}$ \\
\hline Customer Relationship & $\begin{array}{l}\text { Processes/activities for developing and } \\
\text { managing close and long-term } \\
\text { relationships with customers and } \\
\text { improve customer satisfaction. }\end{array}$ & $\begin{array}{l}\text { Li et al., (2005); and Vickery et al. } \\
(2010) .\end{array}$ \\
\hline Postponement & $\begin{array}{l}\text { Processes/activities for moving } \\
\text { forward operations or activities } \\
\text { (making, sourcing, and delivering) to a } \\
\text { much later point in the supply chain }\end{array}$ & $\begin{array}{l}\text { Li et al. (2005); van Hoek (1999); } \\
\text { Beamon (1998); and Davila and } \\
\text { Wouters (2007). }\end{array}$ \\
\hline $\begin{array}{l}\text { Information Systems (IS) } \\
\text { Capability for Agility }\end{array}$ & $\begin{array}{l}\text { The extent to which the firm has } \\
\text { information systems applications that } \\
\text { enable sharing of information with } \\
\text { customers and suppliers, support } \\
\text { market search and monitoring, } \\
\text { facilitate future scenario planning and } \\
\text { aid in the introduction of new products } \\
\text { and services. }\end{array}$ & Sabherwal and Chan, (2001). \\
\hline \begin{tabular}{|l} 
Supply Chain \\
Performance
\end{tabular} & $\begin{array}{l}\text { The extent to which the supply chain } \\
\text { meets end-customer requirements in } \\
\text { terms of product availability and on- } \\
\text { time delivery. }\end{array}$ & $\begin{array}{l}\text { Li et al., (2002); Beamon } \\
\text { (1998); and Vickery et al., (1997). }\end{array}$ \\
\hline
\end{tabular}

Table 1. Definition and references of the study's key constructs 


\subsection{SC practices necessary for ASC strategy}

The ASC strategy has three objectives - 1) supplying products that have a large number of different configurations (features, options, sizes, and color) in different quantities i.e. flexibility (Stevenson and Spring 2007); 2) quick reactions to changes in customer demand, i.e. responsiveness (Huang, Uppal, and Shi 2002; Qi, Zhao, and Sheu 2011); and 3) ability to cope with sudden changes in technology or product life cycles, i.e. adaptability (Whitten, Green Jr., and Zelbst 2012; Lee 2002; Lin, Chiu, and Chu 2006). We theorize next that the following three SC practices (Li et al. 2005) - Strategic Supplier Partnership, Customer Relationship and Postponement - are needed to accomplish these objectives.

Strategic Supplier Partnership describes the activities for developing a close and longterm relationship between the organization and its suppliers ( $\mathrm{Li}$ et al. 2005; Monczka et al. 1998). Such a relationship emphasizes mutual planning, problem solving, and continuous improvement programs with suppliers, and selection of fewer suppliers (Maloni and Benton 1997; Li et al. 2005). It facilitates a high degree of coordination between the organization and its suppliers. It enables collaborative design of new products and knowledge exchange for product development with suppliers, thus enabling flexibility. It also enables the focal firm to collaborate with suppliers to sense demand and detect changes in technologies/products early, thus enabling responsiveness and adaptability (Whitten, Green Jr., and Zelbst 2012).

The Customer Relationship practice describes processes and activities for the focal firm to develop and manage close and long-term relationships with customers. It involves activities such as interaction with customers, processing customer feedback and managing customers' complaints. It enables organizations to develop customized products ( $\mathrm{Li}$ et al. 2005), thus addressing the attribute of flexibility. It also enables tracking of and addressing changes in customer demand preferences and trends, thus addressing the attribute of responsiveness (Vickery et al. 2010; Li et al. 2005).

Postponement is defined as the moving forward of one or more operations or activities (making, sourcing, and delivering) to a much later point in the supply chain and keeping products to their generic form as long as possible until customer orders are received ( $\mathrm{Li}$ et al. 2005; van Hoek 1999; Beamon 1998). It involves keeping materials undifferentiated for as long as possible so as to enable mass customization, make to order, and wider product range, thus addressing the attribute of flexibility. In also enables quick and standardized product assembly to respond quickly to changes in customer demand (Davila and Wouters 2007; van Hoek 1999), thus addressing the attribute of responsiveness.

\subsection{Mediation effect of SC practices on the relationship between ASC strategy and SC performance: Hypotheses 1, 2, 3}

We define SC performance as the extent to which the supply chain is able to meet end-customer requirements of product availability and on-time delivery (Li et al. 2002; Beamon 1998; Vickery, Dröge, and Markland 1997). The ASC strategy transmits its effect on SC performance through the three SC practices describe above.

The ASC strategy transmits its effect on SC performance through the practice of strategic supplier partnership in several ways. First, firms that initiate strategic supplier partnerships are able to accomplish process integration linkages with their suppliers. This helps them pursue initiatives such as sharing ideas, identifying new market opportunities, developing greater knowledge of product raw materials and pursuing a continuous improvement approach with their suppliers (Saeed, Malhotra, and Grover 2011). Given this greater depth and wider range of supplier interactions, focal firms can more flexibly and innovatively deal with changing 
competitive pressures and opportunities. Second, strategic supplier partnership makes it more likely that suppliers will be involved in activities throughout the product life cycle (design, engineering, procurement, delivery, and recycle) and provide early input relating to product design, materials, tools etc. (Vickery et al. 2010), avoiding delays due to changes and re-work and increasing the speed with which these processes can be performed. Third, there is more frequent sharing of information with suppliers (Lai et al. 2012) that makes it possible to quickly analyze and respond to information regarding delivery lead times. Fourth, as integration and information sharing improves among supply chain partners, so too does trust, cooperation and collaboration, over time, leading to joint decision making, design teams and certification programs. These activities, all facilitated by Strategic Supplier Relationship, increase the ability of supply chain partners to improve the overall responsiveness in supplier-interface activities. As an example, Cisco has the ability to "hear the voice of the market" and respond quickly and effectively, by managing its strategic supplier relationships in tandem with an ASC strategy (Lee 2004; Lai et al. 2012). The positive association between the ASC strategy and SC performance is thus realized, in part through strategic supplier partnership. Based on the above arguments, we hypothesize that:

Hypothesis 1. Strategic supplier partnership mediates the relation between the agile supply chain strategy and supply chain performance.

Customer relationship constructively mediates the positive effect of an ASC strategy on SC performance in a number of ways. A close relationship with customers improves information sharing about how a focal firm can determine and satisfy customer requirements (Droge, Vickery, and Jacobs 2012). It enables the firm to continually analyze changes in customer needs, competitive action and product-market options, seek customer feedback and input, and monitor customers' satisfaction and expectations. For example, Koufteros, Rawski, and Rupak (2010) provide evidence that feedback and involvement of customers in product design enables more accurate and timely information transfer that results in fewer deliver-related errors and improves on-time delivery. Regular interaction with customers enables the firm to understand customer preferences and anticipate how they may change over time. It therefore enables the supply chain to cope with changes in the marketplace by effectively meeting customer specifications and responding to changes in customer demand (Ralston et al. 2015). Therefore, the positive association between the ASC strategy and SC performance is realized in part through customer relationship. Based on the above arguments, we hypothesize that:

Hypothesis 2. Customer relationship mediates the relation between the agile supply chain strategy and supply chain performance.

An important aspect of the ASC strategy is a "wait-and-see" approach to demand, that is, not committing to products until demand becomes known (Goldsby, Griffis, and Roath 2006). Keeping materials undifferentiated until customer orders are received (Lee 2004) increases flexibility and responsiveness in the supply chain and enables greater product variety (van Hoek 1999). A critical element to complement the ASC strategy is therefore to carry inventory in a generic form - that is, standard, basic and semi-finished components that can be quickly assembled into different products once customer orders are known (Christopher 2000). One way to do this is through postponement (van Hoek 1999), where customer orders do not have to be 
fully specified during the upstream processes (e.g. ordering and production) (Yang and Burns 2003). The focal firm is able to process the more generic/modular components upfront and incorporate customized features in the later processes for final assembly (Peng, Liu, and Heim 2011). This allows it to quickly produce and deliver a broad range of products. As a practice example, Dell was able to build agility in its supply chains by allowing the customer to configure orders based on certain standard modules and keeping materials undifferentiated to the point till customer demand or order became known (Bruun and Mefford 2004). Postponement thus acts as a bridge between an ASC strategy and SC performance by interjecting flexibility and responsiveness in the supply chain. Based on these arguments we hypothesize:

Hypothesis 3. Postponement mediates the relation between the agile supply chain strategy and supply chain performance.

\subsection{Moderating effect of IS capability for agility on the mediated relationships between ASC strategy and SC performance: Hypotheses $H$ 4, 5, 6}

As discussed for Hypothesis 1, strategic supplier partnership mediates the relationship between ASC strategy and SC performance by enabling process integration, supplier involvement in activities throughout the product life-cycle, knowledge sharing and collaboration. IS capability for agility can further boost all of these conditions, thus positively moderating this mediation effect. For example, it enables the focal firm to monitor market changes, thus increasing the possibility that knowledge of such changes would be shared with suppliers. It increases the ability of the focal firm to share information with suppliers, enhancing the possibility of increased integration with suppliers, supplier involvement in activities throughout the product life-cycle, and collaboration and knowledge transfer (Shah, Goldstein, and Ward 2002). It enables the focal firm to identify alternate courses of action, thus increasing the possibility of sharing knowledge of possible future conditions vis-à-vis with suppliers. Literature suggests that having a strategic relationship with partners requires supporting IS that enable faster decisionmaking (Fawcett et al., 2007) and that higher levels of supplier integration and coordination require higher levels of IS support (Shah, Goldstein, and Ward 2002). By enabling the focal firm to share information with suppliers and customers and monitor changes in the market, an IS capability for agility makes it possible to reduce information processing lead times with suppliers and customers and enable better integration with them (Gunasekaran, Lai, and Cheng 2008). We thus suggest a positive interaction between what IS capability for agility can enable the firm to do and the processes by which the practice of strategic supplier partnership mediates the relationship between ASC strategy and SC performance. Based on the above arguments, we hypothesize that:

Hypothesis 4. Higher the IS capability for Agility, stronger the mediating effect of strategic supplier partnership on the relationship between agile supply chain strategy and supply chain performance.

As discussed under Hypothesis 2, customer relationship practices mediate the relationship between ASC strategy and SC performance by helping the focal firm analyze changes in customer needs, seek customer feedback and monitor customers' satisfaction. IS capability for agility boosts all of these conditions. By enabling information sharing with customers it enhances the focal firm's ability to seek customers' feedback and monitor their 
satisfaction (Sharif, Irani, and Lloyd 2007). By enabling the focal firm to monitor changes in market condition, it provides the focal firm with appropriate support for sensing and responding to customer requirements (Gligor, Esmark, and Holcomb 2015). For example, in spite of using a CRM system, BMW (in the UK) failed to establish strong relationships with its customers because the system did not provide market information on customers and trends, and customer feedback on brands and distribution (Maklan, Knox, and Peppard 2011). Finally, by enabling the focal firm to respond to changes in the market, IS capability for agility enhances its ability to monitor customer satisfaction. Based on these arguments, we suggest a positive interaction between what IS capability for agility can enable the firm to do and the process by which customer relationship practice mediates the relationship between ASC strategy and SC performance. We state hypothesis 5 as follows:

Hypothesis 5. Higher the IS capability for Agility, stronger the mediating effect of customer relationship on the relationship between agile supply chain strategy and supply chain performance.

Postponement mediates the link between ASC strategy and SC performance by enabling the focal firm to quickly produce and deliver a wide range of products. Accurate demand for casting is an important condition for this to happen. IS capability for agility enables the sharing of information with supply chain partners. Such information enables the focal firm to better predict demand and potentially communicate and coordinate real time with supply chain partners (Saldanha et al. 2013). IS capability for agility also enables the firm to monitor changes in customer demand thus reducing the possibility of inaccurate demand forecasts and insufficient resource allocation (Saldanha et al. 2013) and enhancing its ability to quickly manufacture and deliver the required products. For example, Dell transmits real time order information to supply chain partners which enables on-going adjustment of delivery quantities (Bruun and Mefford 2004). Based on these logics we hypothesize that IS capability for agility will positively moderate the mediating effect of postponement on the relationship between ASC strategy and SC performance.

Hypothesis 6. Higher the IS capability for Agility, stronger the mediating effect of postponement on the relationship between agile supply chain strategy and supply chain performance.

\section{Research methods}

The research was executed through the steps of questionnaire design, pilot study, survey data collection, psychometric validation of constructs and hypotheses testing. We describe the steps below.

\subsection{Questionnaire design and pre-test}

The items for the constructs of Strategic Supplier Partnership, Customer Relationship and Postponement were adapted from ( $\mathrm{Li}$ et al. 2005). Those for IS Capability for Agility were adapted from (Sabherwal and Chan 2001). The items for SC performance were adapted from (Li et al. 2002). The ASC strategy construct was developed for the purpose of this study from a review of the literature on supply chain agility (e.g. Qi, Zhao, and Sheu 2011; Huang, Uppal, and Shi 2002; Lee 2002). A 5-point Likert scale with response option ranging from 1 (strongly agree) 
to 5 (strongly disagree) was used to evaluate each item. A sixth option of 'Not Applicable' was also provided.

After item generation, a panel of judges consisting of two practitioners participated in a Q-sort method to qualitatively pre-assess content, convergent and discriminant validities of all constructs. The practitioners were professionals working in the functions of supply chain management in an automotive firm. As such they were expected to have knowledge about the constructs and context of the research model and were thus seemed suitable as 'judges' for the Q-sort. Three rounds of Q-sort were needed by each to secure a 98\% hit ratio score, a 95\% interjudge raw correct agreement score 95\%, and 95\% Kappa coefficient score. All scores represent an excellent level of agreement among the judges (Moore and Benbasat 1991; Cohen 1960; Jarvenpaa 1989).

\subsection{Data collection}

The questionnaires were sent out to 3129 supply chain professionals (with the designations of directors, vice-presidents and senior managers of purchase/materials management/logistics/supply chain) for manufacturing firms located in the United States. The names and contacts were obtained through a purchased mailing list from a data provider. The data were collected using a Web-based survey. The survey needed 15 minutes to be completed. A total of 205 senior executives (directors, vice presidents and senior managers) from purchasing/production/supply chain functions) completed the survey representing a response rate of $6.6 \%$. Phone calls were made to make sure that the respondents were indeed from these ranks and departments and were qualified to take the survey. Table 2 shows that most of the organizations have annual sales of more than one million in USD. Table 3 shows that the majority of organizations are manufacturing organizations.

\begin{tabular}{|l|l|l|}
\hline Annual Sales in US S & Number of firms & Percentage \\
\hline$>1$ Billion & 42 & $20 \%$ \\
\hline $500-1000$ Million & 19 & $9 \%$ \\
\hline $250-500$ Million & 22 & $11 \%$ \\
\hline $50-250$ Million & 33 & $16 \%$ \\
\hline $25-50$ Million & 40 & $20 \%$ \\
\hline $10-25$ Million & 27 & $13 \%$ \\
\hline $1-10$ Million & 20 & $10 \%$ \\
\hline $0-1$ Million & 2 & $1 \%$ \\
\hline
\end{tabular}

Table 2. Annual sales of respondent firms in US dollars

\begin{tabular}{|l|l|l|}
\hline Industry Category & Number of firms & Percentage \\
\hline Manufacturing & 170 & $84 \%$ \\
\hline Service & 3 & $1 \%$ \\
\hline Process Industry & 7 & $3 \%$ \\
\hline *Other & 25 & $12 \%$ \\
\hline
\end{tabular}

* Other category such as retail, distribution, logistics, design, and overhaul/repair.

Table 3. Industry categories of respondent firms 


\subsection{Non-response bias and common method bias}

We collected data over two rounds; the first round had 77 responses, the second had 128 responses. We assessed non-response bias using the Chi square test. We tested whether the first round of responses differed significantly from the second round of responses based on industry category, and annual firm sales. We did not find any significant difference between the two rounds along these two criterions, indicating that non-response bias is not a major concern for this study.

We further tested for common method bias using two methods - Harman's single factor test and method variable test (Podsakoff et al. 2003). For first method, we conducted an exploratory factor analysis for all survey items. This test revealed that one factor accounted for $22.7 \%$ of the variance explained. This means that no one factor emerged that counted for more than $50 \%$ of the variance explained, which suggests that common method bias is not a major concern in this study (Podsakoff et al. 2003). For the second test we allowed all indicator items to load on their construct, as well as on a latent 'method' factor. The common variance accounted for $3.1 \%$ of the total variance, and there was no change in the model's relationships and construct loadings, which remained significant. These results reinforce that common method bias is not a major concern in this study (Podsakoff et al. 2003).

\subsection{Assessment of construct psychometric properties}

Unidimensionality of each construct was established using an exploratory factor analysis using principal components as means of extraction and VARIMAX as the method of rotation. Table 4 shows the construct items and factor loadings. 


\begin{tabular}{|c|c|c|}
\hline \multicolumn{2}{|c|}{$\begin{array}{ll}\text { Construct } \\
\end{array}$} & $\begin{array}{c}\text { Factor } \\
\text { Loading }\end{array}$ \\
\hline \multicolumn{2}{|r|}{ Agile Supply Chain Strategy (ASC) } & \\
\hline & \multicolumn{2}{|l|}{ Our supply chain aims to: } \\
\hline ASC 1 & Respond effectively to changing requirements of design & .81 \\
\hline $\mathrm{ASC} 22$ & Handle changes in product design & .75 \\
\hline $\mathrm{ASC} 3$ & Respond quickly to customization requirements & .79 \\
\hline ASC_4 & $\begin{array}{l}\text { Customize our products by adding feature models as per our } \\
\text { requirements }\end{array}$ & .80 \\
\hline $\mathrm{ASC} 5$ & Maintain a higher capacity buffer to response to volatile market & .77 \\
\hline \multicolumn{3}{|c|}{ Strategic Supplier Partnership (SSP) } \\
\hline & \multicolumn{2}{|l|}{ With regards to partnerships with our suppliers: } \\
\hline SSP_1 & We select suppliers based on their quality & .76 \\
\hline SSP_2 & We solve problems jointly with our suppliers & .76 \\
\hline SSP_3 & $\begin{array}{l}\text { We introduce our key suppliers in our planning and goal-setting } \\
\text { activities }\end{array}$ & .61 \\
\hline \multicolumn{3}{|c|}{ Customer relationship (CR) } \\
\hline & \multicolumn{2}{|l|}{ With regards to relationships with our customers, we: } \\
\hline CR_1 & $\begin{array}{l}\text { Interact with customers to set reliability, responsiveness, and other } \\
\text { standards for us }\end{array}$ & .69 \\
\hline CR 2 & Measure and evaluate customer satisfaction & .82 \\
\hline CR 3 & Determine future customer expectations & .83 \\
\hline CR_4 & Facilitate customers' ability to seek assistance from us & .86 \\
\hline \multicolumn{3}{|c|}{ Postponement (POS) } \\
\hline & \multicolumn{2}{|l|}{ In our supply chain, we: } \\
\hline POS_1 & $\begin{array}{l}\text { Delay final product assembly activities until customer orders have } \\
\text { actually been received }\end{array}$ & .85 \\
\hline POS_2 & $\begin{array}{l}\text { Delay final product assembly activities until the last possible } \\
\text { position (or nearest to customers) in the supply chain }\end{array}$ & .88 \\
\hline POS_3 & $\begin{array}{l}\begin{array}{l}\text { Store our parts/products at distribution points closer to the } \\
\text { customer }\end{array} \\
\end{array}$ & .62 \\
\hline POS_4 & Design products for modular assembly & .70 \\
\hline \multicolumn{3}{|c|}{ Information Systems Capability for Agility (ISCA) } \\
\hline & \multicolumn{2}{|c|}{$\begin{array}{l}\text { The information systems applications we have in the supply chain support } \\
\text { us to: }\end{array}$} \\
\hline ISCA_1 & Introduce new product and/or service in our markets & .78 \\
\hline ISCA_2 & Share information with our suppliers and customers & .64 \\
\hline ISCA_3 & Monitor changes in our market condition & .68 \\
\hline ISCA_4 & Respond to changes in the market. & .80 \\
\hline ISCA_5 & $\begin{array}{l}\text { Model possible future outcomes and identify alternative courses of } \\
\text { action }\end{array}$ & .65 \\
\hline \multicolumn{3}{|c|}{ Supply Chain Performance (SCPer) } \\
\hline & \multicolumn{2}{|l|}{ Our supply chain does: } \\
\hline SCPer_1 & Handle difficult nonstandard orders & .79 \\
\hline SCPer_2 & Meet special customer specification & .76 \\
\hline SCPer_3 & $\begin{array}{l}\text { Produce products characterized by numerous features options, } \\
\text { sizes and colors }\end{array}$ & .79 \\
\hline SCPer_4 & $\begin{array}{l}\text { Rapidly adjusts capacity so as to accelerate or decelerate } \\
\text { production in response to changes in customer demand }\end{array}$ & .72 \\
\hline SCPer_5 & $\begin{array}{l}\text { Rapidly introduces large numbers of product } \\
\text { improvements/variation }\end{array}$ & .82 \\
\hline
\end{tabular}

Table 4. Construct items and factor loadings 
We next assessed the convergent and discriminant validity of each construct using confirmatory factor analysis (CFA) through AMOS. Specifically, we analyzed a measurement model that had all the constructs - ASC Strategy, Strategic Supplier Partnership, Customer Relationship, Postponement, IS Capability for Agility, and SC Performance - correlated. The results are as follows: $\chi^{2} / \mathrm{df}=3.11$; GFI $=.90$; CFI $=.93$; AGFI $=.87$; $\mathrm{RMR}=.04$. These results indicate good convergent and discriminant validity of the constructs according to Gaskin (Gaskin 2011). We also assessed the composite reliability of each construct as shown in Table 5. We further assessed the discriminant validity using average variance extracted (AVE); maximum shared variance (MSV) and average shared variance (ASV). The results, described in in Table 5 show that the MSV values and ASV values are < than the AVE values for each construct, indicating good discriminant validity among them (Hair et al. 2010). Further, the square root of the AVE for each construct (reported on the diagonal) is greater than the correlation of that construct to all other constructs, reinforcing good discriminant validity (Chin 1998).

\begin{tabular}{|l|l|l|l|l|l|l|l|l|l|l|}
\hline & $\begin{array}{l}\text { Composite } \\
\text { Reliability }\end{array}$ & ASC & SSP & CR & POS & ISCA & SCPer & $\begin{array}{l}\text { Average } \\
\text { Variance } \\
\text { Extracted } \\
\text { (AVE) }\end{array}$ & $\begin{array}{l}\text { Maximum } \\
\text { Shared } \\
\text { Variance } \\
\text { (MSV) }\end{array}$ & $\begin{array}{l}\text { Average } \\
\text { Shared } \\
\text { Variance } \\
\text { (ASV) }\end{array}$ \\
\hline ASC & $\mathbf{0 . 9 2}$ & $\underline{0.84}$ & & & & & & $\mathbf{0 . 7 1}$ & $\mathbf{0 . 2}$ & $\mathbf{0 . 0 8}$ \\
\hline SSP & $\mathbf{0 . 7 5}$ & 0.20 & $\underline{0.72}$ & & & & & $\mathbf{0 . 5 1}$ & $\mathbf{0 . 3 8 2}$ & $\mathbf{0 . 1 3}$ \\
\hline CR & $\mathbf{0 . 8 5}$ & 0.13 & 0.44 & $\underline{0.78}$ & & & & $\mathbf{0 . 6 0}$ & $\mathbf{0 . 1 9}$ & $\mathbf{0 . 0 7}$ \\
\hline POS & $\mathbf{0 . 7 9}$ & 0.52 & 0.04 & 0.01 & $\underline{0.71}$ & & & $\mathbf{0 . 5 0}$ & $\mathbf{0 . 2 7}$ & $\mathbf{0 . 0 6}$ \\
\hline ISCA & $\mathbf{0 . 8 9}$ & 0.20 & 0.33 & 0.13 & 0.21 & $\underline{0.90}$ & & $\mathbf{0 . 8 2}$ & $\mathbf{0 . 2 3}$ & $\mathbf{0 . 0 7}$ \\
\hline SCPer & $\mathbf{0 . 8 4}$ & 0.35 & 0.30 & 0.20 & 0.26 & 0.12 & $\underline{0.72}$ & $\mathbf{0 . 5 2}$ & $\mathbf{0 . 1 2}$ & $\mathbf{0 . 0 6}$ \\
\hline
\end{tabular}

Table 5. Composite reliability, average variance extracted, maximum shared variance and average shared variance

\subsection{Hypothesis testing and results}

We tested our hypotheses by conducting a bootstrapping test using structural equation modeling analysis with AMOS software and followed the steps suggested in the literature for testing mediated relationships as suggested in the literature (Preacher, Rucker, and Hayes 2007; Kenny 2011). In the first step we tested for the direct effect of agile ASC strategy on SC performance without any mediating variables. The results indicate that the direct effect of ASC strategy on SC performance is significant with beta coefficient of .31; this regression weight significantly different from zero at the 0.001 level (two-tailed). In the second step we added the following mediating variables (SC practices): Strategic Supplier Partnership, Customer Relationship and Postponement, one at a time and tested for the direct and indirect effect of ASC strategy on SC performance with the presence of each mediator. We ran a total of 3 models with 2000 bootstrapped samples and 95\% confidence level for each model as recommended by (Kenny 2011). For each model, we looked at the standardized (1) direct effect (Beta values) of ASC strategy on SC performance with the presence of each of the mediating variables (SC practices), and (2) indirect effect (Beta values) of ASC strategy on SC performance with the presence of each of the mediating variable. We also looked at the bootstrap confidence (bias-corrected percentile method) to find whether those values are significant. The results, summarized in Table 6, indicate that hypotheses $\mathrm{H} 1$ and $\mathrm{H} 3$ are supported. That is, strategic supplier partnership fully 
mediates the relationship between ASC strategy and SC performance, and postponement partially mediates the relationship between ASC strategy and SC performance. H2 is not supported. Analytically, questions of "how" are typically approached using mediation analysis. Support for $\mathrm{H} 1$ and $\mathrm{H} 3$ thus indicates that ASC boosts SC performance through the positive mediation of strategic supplier partnership and postponement.

\begin{tabular}{|l|l|l|l|l|}
\hline Hypothesis & $\begin{array}{l}\text { Direct } \\
\text { Beta } \\
\text { without } \\
\text { Med }\end{array}$ & $\begin{array}{l}\text { Direct Beta } \\
\text { with Med }\end{array}$ & Indirect Beta & $\begin{array}{l}\text { Mediation type } \\
\text { observed }\end{array}$ \\
\hline H1:ASC-SSP-SCPer & $.31 * * *$ & $.036(\mathrm{NS})$ & $.275^{* * *}$ & Full Mediation \\
\hline H2:ASC-CR-SCPer & $.31 * * *$ & $.294^{* * *}$ & $.072(\mathrm{NS})$ & No Mediation \\
\hline H3:ASC-POS- SCPer & $.31 * * *$ & $.268 * * *$ & $.043^{*}$ & Partial Mediation \\
\hline
\end{tabular}

Table 6. Results for Mediation: Hypotheses H1, H2 and H3

***Significant at .001 level

** Significant at .01 level

* Significant at .05 level

To test for the moderated-mediation relationship, we used the PROCESS Analysis method (Hayes 2013, pp. 329-355) using the bootstrapping strategies in SPSS. This method uses an ordinary least square (OLS) or logistic regression-based path analytical framework for moderated-mediation models. The moderated-mediation occurs when the strength of the mediated relationship (that is, of ASC on SC performance mediated through each of the three SC practices) depends on the level of another variable (that is, IS capability for agility). That is, when the strength of the mediation relationship is contingent on the level of the moderator (Preacher, Rucker, and Hayes 2007). The results of the moderation of the mediated relationships are summarized in Table 7 . We find that IS capability for agility positively moderates (strengthens) the mediated effects of all three SC practices - Strategic Supplier Partnership, Postponement and Customer Relationship - on the relationship between ASC strategy and SC performance. That is, the conditional indirect effect of ASC strategy on SC performance, through each of the three SC practices, differs in strength between low and high levels of IS capability for agility. This indicates that H4, H5 and H6 are all supported. Analytically, questions of "when" are typically answered through moderation analysis. Support for H4, H5 and H6 indicates that the mediating/boosting effect of the three SC practices are higher when IS capability for agility is also present.

We also calculated the strength of the three moderated -mediated relationships, that is, the magnitude of the indirect effect of ASC on SC performance, mediated by each of the three SC practices, and simultaneously moderated by IS capability for agility. In all three cases we found this moderated-mediated relationship significant. The moderated-mediation relationship thus allows us to analyze both "how" and "when" simultaneously. 


\begin{tabular}{|l|l|l|l|}
\hline Hypothesis & $\begin{array}{l}\text { Regression } \\
\text { Coefficient }\end{array}$ & T Value & $\begin{array}{l}\text { Moderation of } \\
\text { Mediated Relationship }\end{array}$ \\
\hline $\begin{array}{l}\text { H4: Interaction } \\
\text { Mediated effect of SSP } \quad \mathrm{x} \quad \text { ISCA }\end{array}$ & $.090 * *$ & 2.57 & Significant Positive \\
\hline $\begin{array}{l}\text { H5: Interaction } \\
\text { Mediated effect of CR x ISCA }\end{array}$ & $.167 * *$ & 2.21 & Significant Positive \\
\hline $\begin{array}{l}\text { H6: Interaction } \\
\text { Mediated effect of POS x ISCA }\end{array}$ & $.190 * * *$ & 4.05 & Significant Positive \\
\hline
\end{tabular}

Table 7. Results for Moderation of Mediated Relationships: Hypotheses H4, H5 and H6

*** Significant at .001 level

** Significant at .01 level

* Significant at .05 level

\section{Contributions to theory and practice}

The focal firm's ability to adjust its production and manufacturing depends on the ability of its supply chain to quickly alter key aspects such as delivery quantities and schedule. Supply chain agility, which embodies the firm's ability to quickly adjust its tactics and operations, enables the firm to produce and manufacture in adaptation to high product variety and sudden changes in product volume, and to sense and react to changing requirements of the market. Understanding how supply chain agility affects performance is thus an important conceptual contribution to the study of how firms can produce and deliver effectively in the face of volatile demand, dynamic markets and short product life cycles. Yet, there has been little empirical research that addresses the relationship between supply chain agility and performance (Gligor, Esmark, and Holcomb 2015). In this paper we explain how the presence of particular supply chain practices and information processing capabilities can effect a positive relationship between an agile supply chain strategy and supply chain performance, and in doing so contribute to research that seeks to understand how the firm can produce to varying demands and markets.

The first theoretical contribution of the paper is in capturing complementarity between an ASC strategy and particular SC practices, thus providing insight regarding how ASC strategy can boost SC performance through the mediating effect of these practices. We extend current studies that primarily focus on antecedents of supply chain agility or its impact on the focal firm's financial performance. A second theoretical contribution is in showing that an IS capability for agility, embodied in the existence of applications in the focal firm that facilitate information sharing with suppliers and partners, aid in market scanning and new product introduction and help in analyzing possible future scenarios, boosts these mediating effects. In examining the role of IS in the supply chain, past research has examined inter-organizational concepts such as trust, collaboration, innovation and knowledge sharing (e.g. Subramani 2004). However the interaction between IS with specific supply chain practices, that is, how IS capability for agility reinforces the effect of SC practices to enhance SC performance from agility, has not been studied. This is a contribution for this paper.

Specifically, we find that strategic supplier partnership is necessary to effect a positive relationship between ASC strategy and SC performance, through a fully mediating effect (H1 supported). Moreover the strength of its effect, in our study, was enhanced by the presence of IS capability for agility (H4 supported). This shows that the beneficial impact of an ASC strategy 
on SC performance that happens through the mediation of strategic supplier partnership is further enhanced when the focal firm implements applications that embody IS capability for agility. Similarly we find that postponement has a positive linking effect between ASC strategy and SC performance, through partial mediation (H3 supported), which is made stronger by the presence of IS capability for agility (H6 supported).

Interestingly we find that while the mediating effect of customer relationship is not significant (H2 not supported), the moderating effect of IS capability for agility on the mediated relationship is significant (H5 supported). Further, the magnitude of the indirect effect of ASC on SC performance in the presence of both customer relationship (mediation) and IS capability for agility (moderation) is significant. Such an effect has been described in the literature (Hayes 2013) as "An indirect effect could be contingent on a moderator variable," or "The indirect effect of X (independent) on Y (dependent) through M (mediator) existed only when V (moderator was there)". Statistically this means that if we want to study the effect of X on Y through a mediating variable $\mathrm{M}$, this relationship if not significant, could become so when adding a moderator $\mathrm{V}$. In terms of our results, this means that in order for customer relationship to effectively mediate the relationship between ASC strategy and SC performance, the supporting and amplifying effects of information systems that enable the monitoring of changes in market conditions, sharing of information with customers and introduction of new products are required. Such IS support the processes of gathering, collecting and analyzing data on demand and customer preferences, providing a boost for the firm's efforts in increasing customer intimacy, satisfaction and loyalty (Wang, Hu, and Hu 2013). This finding that customer relationship is effective in appropriating enhanced SC performance from ASC strategy only in the presence of an IS capability for agility, suggests an important contingency aspect not examined in the literature.

Our findings have implications for managerial practice regarding supply chain practices and information systems applications that are helpful for agile supply chains. To begin with, all of the three practices that we examined do not have similar effects in linking agility and SC performance. While supplier partnership practice is likely to be essential, postponement appears partially so. There is thus a good case for developing these practices, for focal firms that have an ASC strategy. Concurrently, the presence of IS capability for agility, that is, the existence of applications in the focal firm that facilitate information sharing with suppliers and partners, aid in market scanning and new product introduction and help in analyzing possible future scenarios, is also essential for further boosting SC performance. A word of caution is perhaps helpful here. While the focal firm may implement applications which might provide the functionality required for IS capability for agility, that functionality may not be realized in practice due to lack of similar IS in suppliers. For instance, suppliers may not have the technology sophistication required to implement IS capability for agility, may have applications that do not support an IS capability for agility, or may have incompatible data and interface standards. Alignment of IS between the focal firm and its suppliers is thus important for IS capability for agility to be helpful. Counter intuitively, the customer relationship practice by itself may not generate superior SC performance from ASC strategy, unless IS capability for agility is also present. Applications that facilitate information sharing with suppliers and partners, aid in market scanning and new product introduction and help in analyzing possible future scenarios are thus essential for customer relationship to boost the positive link between ASC strategy and SC performance. Based on these findings therefore, we suggest that the matter of practically effecting enhanced SC performance from an ASC strategy through SC practices and IS that 
facilitate agility, requires careful consideration of specific contingencies and complementing relationships.

\section{Limitations, future research and conclusion}

While we took the recommended precautions in designing and executing this study, the paper is subject to limitations typical of most survey research. First, the results represent a cross-sectional snapshot in time and lack the ability to capture motivations of individual participants as is possible with qualitative methods. Second there is the possibility of common methods bias since a single respondent answered all questions. While we did not statistically find common method problems in our study, it cannot be completely ruled out. Third, a majority of our respondent organizations are more than 10 years old. While this is perhaps an important criterion for achieving some level of maturity in deployment of information systems in the supply chain, it does raise the question of whether the relationships we examine in this paper would be qualitatively different for smaller focal firms.

Our results suggest potentially productive directions for future research. In taking further, the idea of complementarity between supply chain strategy and practices, research could examine SC practices that can link other supply chain strategies such as lean, with SC performance. Also, studies that dig deeper into our counter-intuitive findings regarding the customer relationship practice might identify additional conditions under which these findings may or may not hold. Finally, our study was conducted on firms in the manufacturing sector; similar studies in service sectors such as retail or healthcare may identify interesting comparisons.

In conclusion, this paper addresses current literature needs for understanding how and why an ASC strategy can improve SC performance. First, adopting a complementarity perspective we suggest that certain SC practices act as a positive mediating link between ASC strategy and SC performance, boosting the effects of the former on the latter. Then, based on the information processing view of the supply chain we further suggest that an IS capability for agility can strengthen the links provided by these practices. 


\section{References}

Beamon, B.M., 1998, Supply chain design and analysis: Models and methods, International Journal of Production Economics, 55, 3, 281-294.

Blome, C., Schoenherr, T., Rexhausen, D., 2013, Antecedents and enablers of supply chain agility and its effect on performance: a dynamic capabilities perspective, International Journal of Production Research, 51, 4, 1295-1318.

Bruun, P., Mefford, R.N., 2004, Lean production and the Internet, International Journal of Production Economics, 89, 3, 247-260.

Cecere, L., 2012, Sales and operations planning improves supply chain agility, Supply Chain Insight.

Chin, W.W., 1998, The partial least squares approach to structural equation modeling. In Modern Methods for Business Research, edited by Marcoulides, G.A. Lawrence Erlbaum Associates, Hillsdale, NJ.

Christopher, M., 2000, The agile supply chain: competing in volatile markets, Industrial marketing management”, 29, 1, 37-44.

Cohen, J., 1960, A coefficient of agreement for nominal scales, Educational and Psychological Measurement, 20, 37-46.

Davila, T., Wouters, M., 2007, An empirical test of inventory, service and cost benefits from a postponement strategy, International Journal of Production Research, 45,10, 2245-2267.

Droge, C., Vickery, S.K., Jacobs, M.A., 2012, Does supply chain integration mediate the relationships between product/process strategy and service performance? An empirical study, International Journal of Production Economics, 137, 2, 250-262.

Fawcett, S. E., Osterhaus, P., Magnan, G., Brau, J.C., McCarter, M.W., 2007, Information sharing and supply chain performance: the role of connectivity and willingness, Supply Chain Management: An International Journal, 12, 5, 358-368.

Ferdows, K., Lewis, M.A., Machuca, J.A., 2004, Rapid-fire fulfillment, Harvard Business Review, 82, 11, 104-117.

Fisher, M.L., 1997, What is the right supply chain for your product?, Harvard Business Review, 75, 105-117.

Galbraith, J.R. 1973, Designing complex organizations, Reading, Addison-Wesley Longman Publishing Co., Inc., MA. 
Gaskin, J. 2011, "Model fit during a Confirmatory Factor Analysis (CFA) in AMOS", available at: http://statwiki.kolobkreations.com/wiki/Confirmatory_Factor_Analysis (accessed March 2013).

Gligor, D.M., Esmark, C.L., Holcomb, M.C., 2015, Performance outcomes of supply chain agility: When should you be agile?, Journal of Operations Management, 33-34, 71-89.

Goldsby, T.J., Griffis, S.E., Roath, A.S., 2006, Modeling lean, agile, and leagile supply chain strategies, Journal of Business Logistics, 27, 1, 57-80.

Gunasekaran, A., Lai, K.H., Cheng, T.E., 2008, Responsive supply chain: a competitive strategy in a networked economy, Omega, 36, 4, 549-564.

Gunasekaran, A., Patel, C., Tirtiroglu, E., 2001, Performance measures and metrics in a supply chain environment, International Journal of Operations \& Production Management, 21, 1-2, 7187.

Hair, J., Black, W., Babin, B., Anderson, R., 2010, Multivariate Data Analysis, Prentice Hall, Inc., Upper Saddle River, NJ.

Hayes, A. F, 2013, Introduction to Mediation, Moderation, and Conditional Process Analysis, The Guilford Press, New York, London.

Huang, S. H., Uppal, M., Shi, J. 2002, A product driven approach to manufacturing supply chain selection, Supply Chain Management: An International Journal, 7, 4, 189-199.

Jarvenpaa, S.L., 1989, The Effect of Task Demands and Graphical Format on Information Processing Strategies, Management Science, 35, 3, 285-303.

Kenny, D., 2011, available at: http://davidakenny.net/cm/ mediate.htm (accessed 21 December 2011).

Koufteros, X. A., Rawski, G.E., Rupak, R., 2010, Organizational integration for product development: The effects on glitches, on-time execution of engineering change orders, and market success, Decision Sciences, 41, 1, 49-80.

Lai, F., Zhang, M., Lee, D. M., Zhao, X., 2012, The Impact of Supply Chain Integration on Mass Customization Capability: An Extended Resource-Based View, Engineering Management, IEEE Transactions on, 59, 3, 443-456.

Lao, Y., Hong, P., Rao, S.S., 2010, Supply Management supply flexibility and performance outcomes: an empirical investigation of manufacturing firms, Journal of Supply Chain Management, 46, 3, 6-22.

Lee, H.L., 2002, Aligning supply chain strategies with product uncertainties, California Management Review, 44, 3, 105-119. 
Lee, H.L. 2004, The triple-A supply chain, Harvard Business Review, 82, 10, 102-113.

Li, S., Rao, S.S., Ragu-Nathan, T.S., Ragu-Nathan, B., 2005, Development and validation of a measurement instrument for studying supply chain management practices, Journal of Operations Management, 23, 6, 618-641.

Li, S., Rao, S.S., Ragu-Nathan, T.S., Ragu-Nathan, B., 2002, An integrated model for supply chain management practice, performance and competitive advantage, Doctoral Dissertation, The University of Toledo.

Lin, C., Chiu, H., Chu, P., 2006, Agility index in the supply chain, International Journal of Production Economics, 100, 2, 285-299.

Maklan, S., Knox, S., Peppard, J., 2011, Why CRM fails - and how to fix it, MIT Sloan Management Review, 52, 4, 77-85.

Maloni, M.J., Benton, W.C., 1997, Supply chain partnerships: Opportunities for operations research. European Journal of Operational Research, 101, 3, 419-429.

McLaren, T.S., Head, M.M., Yuan, Y., 2004, Supply chain management information systems capabilities. An exploratory study of electronics manufacturers, Information systems and Ebusiness management, 2, 2-3, 207-222.

Milgrom, P., Roberts, J.,1995, Complementarities and fit strategy, structure, and organizational change in manufacturing, Journal of Accounting and Economics, 19, 2, 179-208.

Monczka, R.M., Petersen, K.J., Handfield, R.B., Ragatz, G.L., 1998, Success factors in strategic supplier alliances: The buying company perspective”, Decision Sciences, 29, 3, 553-577.

Moore, G.C., Benbasat, I., 1991, Development of an instrument to measure the perceptions of adopting an information technology innovation, Information Systems Research, 2, 3, 192-222.

Peng, D.X., Liu, G.J., Heim, G.R., 2011, Impacts of information technology on mass customization capability of manufacturing plants, International Journal of Operations \& Production Management, 31, 10, 1022-1047.

Podsakoff, P.M., MacKenzie, S.B., Lee, J.Y., Podsakoff, N.P., 2003, Common method biases in behavioral research: a critical review of the literature and recommended remedies, Journal of Applied Psychology, 88, 5, 879-903.

Porter, M.E., 1996, What is strategy?, Harvard Business Review, 75, 1, 61-78.

Preacher, K.J., Rucker, D.D., Hayes, A.F., 2007, Assessing moderated mediation hypotheses: theory, method, and prescriptions, Multivariate Behavioral Research, 42, 1, 185-227. 
Premkumar, G., Ramamurthy, K., Saunders, C.S., 2005, Information processing view of organizations: an exploratory examination of fit in the context of interorganizational relationships, Journal of Management Information Systems, 22, 1, 257-294.

Purvis, L., Gosling, J., Naim, M.M. 2014, The development of a lean, agile and leagile supply network taxonomy based on differing types of flexibility, International Journal of Production Economics, 151, 100-111.

Qi, Y., Zhao, X., Sheu, C., 2011, The Impact of Competitive Strategy and Supply Chain Strategy on Business Performance: The Role of Environmental Uncertainty, Decision Sciences, 42, 2, 371-389.

Rai, A., Patnayakuni, R., Seth, N., 2006, Firm performance impacts of digitally enabled supply chain integration capabilities MIS Quarterly, 225-246.

Ralston, P.M., Blackhurst, J., Cantor, D.E., Crum, M.R., 2015, A Structure-ConductPerformance Perspective of How Strategic Supply Chain Integration Affects Firm Performance, Journal of Supply Chain Management, 51, 2, 47-64.

Sabherwal, R., Chan, Y.E., 2001, Alignment between business and IS strategies: a study of prospectors, analyzers, and defenders, Information Systems Research, 12, 1, 11-33.

Saeed, K.A., Malhotra, M.K., Grover, V., 2011, Interorganizational System Characteristics and Supply Chain Integration: An Empirical Assessment, Decision Sciences, 42, 1, 7-42.

Saldanha, T.J., Melville, N.P., Ramirez, R., Richardson, V.J. 2013, Information systems for collaborating versus transacting: Impact on manufacturing plant performance in the presence of demand volatility, Journal of Operations Management, 31, 6, 313-329.

Sanders, N.R., 2008, Pattern of information technology use: The impact on buyer-suppler coordination and performance, Journal of Operations Management, 26, 3, 349-367.

Saraf, N., Langdon, C.S., Gosain, S. 2007, IS application capabilities and relational value in interfirm partnerships, Information Systems Research, 18, 3, 320-339.

Shah, R., Goldstein, S.M., Ward, P.T. (2002), Aligning supply chain management characteristics \& inter-organizational information system types: An exploratory study, IEEE Transactions on Engineering Management, 49, 3, 282-292.

Sharif, A.M., Irani, Z., Lloyd, D., 2007, Information technology and performance management for build-to-order supply chains, International Journal of Operations \& Production Management, 27, 11, 1235-1253.

Stevenson, M., Spring, M., 2007, Flexibility from a supply chain perspective: definition and review, International Journal of Operations \& Production Management, 27, 7, 685-713. 
Subramani, M., 2004, How do suppliers benefit from information technology use in supply chain relationships?, MIS Quarterly, 45-73.

Swafford, P.M., Ghosh, S., Murthy, N., 2006, The antecedents of supply chain agility of a firm: scale development and model testing”, Journal of Operations Management, 24, 2, 170-188.

van Hoek, R.I. 1999, Postponement and the reconfiguration challenge for food supply chains, Supply Chain Management: An International Journal, 4, 1, 18-34.

Vickery, S.K., Droge, C., Setia, P., Sambamurthy, V., 2010, Supply chain information technologies and organisational initiatives: complementary versus independent effects on agility and firm performance, International Journal of Production Research, 48, 23, 7025-7042.

Vickery, S.K., Dröge, C., Markland, R.E. 1997, Dimensions of manufacturing strength in the furniture industry, Journal of Operations Management, 15, 4, 317-330.

Wang, E.T., Hu, H.F., Hu, P.J.H., 2013, Examining the role of information technology in cultivating firms' dynamic marketing capabilities, Information \& Management, 50, 6, 336-343.

Whitten, G. D., Green Jr, K. W. and Zelbst, P. J. (2012), “Triple-A supply chain performance, International Journal of Operations \& Production Management, Vol. 32 No. 1, pp. 28-48.

Yang, B., Burns, N.D., 2003, Implications of postponement for the supply chain, International Journal of Production Research, 41, 9, 2075-90.

Yusuf, Y.Y., Gunasekaran, A., Adeleye, E.O., Sivayoganathan, K., 2004, Agile supply chain capabilities: Determinants of competitive objectives, European Journal of Operational Research, 159, 2, 379-392. 